\title{
Effect of inventory plot patterns in the floristic analysis of tropical woodland and dense forest
}

\author{
Georges Houeto $^{1}$, Romain Glele Kakaï ${ }^{1 *}$, Valère Salako ${ }^{1}$, Belarmain Fandohan ${ }^{1}$, \\ Achille E. Assogbadjo ${ }^{1}$, Brice Sinsin ${ }^{1}$ and Rodolphe Palm ${ }^{2}$ \\ ${ }^{1}$ Laboratory of applied ecology, Faculty of Agronomic sciences, University of Abomey-Calavi, 01 BP 526, Cotonou, Benin and ${ }^{2}$ Université de Liège, \\ Gembloux Agro-Bio Tech, SIMa, Avenue de la Faculté d'Agronomie 8, B-5030 Gembloux, Belgique
}

\begin{abstract}
This study was set up to examine the effect of plot patterns on the accuracy of phytosociological characterization of tropical vegetation. Fifteen and twenty square plots of 1 ha were demarcated, respectively, in woodland and dense forest in Bénin. Each 1 ha plot was divided into 100 quadrats of one $100 \mathrm{~m}^{2}$. Species of trees in each quadrat were identified and recorded. The cost in terms of time required to record tree species in each 1 ha plot and five random quadrats in a 1 ha plot were also recorded to compute the mean inventory effort for a team of three foresters. From the 100 quadrats in a 1 ha plot, fourteen independent subplots of square and rectangular plots with different sizes were considered by grouping together adjacent quadrats of $100 \mathrm{~m}^{2}$. Eigenanalysis was carried out to compare the subplots. Moreover, the relationship between the relative loss of accuracy (RLA) and the size of subplots was modelled. Plot size highly influenced the RLA $(P<0.05)$. Findings indicated that the square plots of 1500 and $1000 \mathrm{~m}^{2}$ with an inventory effort of 0.35 and 0.20 man-days per subplot, respectively in tropical dense forests and woodlands appeared to be the most efficient in the phytosociological characterization of woody vegetation.
\end{abstract}

Key words: Bénin, efficiency, eigenanalysis, floristic analysis, inventory plot, vegetation

\section{Résumé}

Cette étude a été réalisée pour évaluer l'effet de la taille et de la forme des relevés sur la précision de la caractérisation phytosociologique de la végétation en milieu tropical. A cet effet, dans une forêt claire et dans une forêt dense du

*Correspondence: E-mail: gleleromain@yahoo.fr
Benin, respectivement 15 et 20 placeaux carrées d'un ha furent délimitées, et chacun fut divisé en 100 quadrats de $100 \mathrm{~m}^{2}$. Les espèces de tous les arbres rencontrés dans chaque quadrat furent identifiées et notées. De plus, le coût en termes de temps nécessaire pour identifier et noter les espèces d'arbres de chaque placeau d'un ha et celui lié á cinq quadrats pris au hasard dans un placeau d'un ha sont notés, afin de connaître l'effort d'inventaire moyen pour une équipe de trois forestiers. A partir des 100 quadrats de $100 \mathrm{~m}^{2}$ d'un placeau d'un placeau de 1 ha, 14 placettes indépendantes de différentes formes (carrée ou rectangulaire) et de taille variable furent considérées en regroupant des quadrats adjacents de $100 \mathrm{~m}^{2}$. Une analyse des valeurs propres (eigenanalysis) fut faite pour comparer les placettes. De plus, la relation entre la perte relative de précision (PRP)et la taille des placettes fut modélisée. La taille des placettes influençait fortement la PRP $(P<0,05)$. Les résultats ont montré que les placeaux de 1500 et de $1000 \mathrm{~m}^{2}$, avec un effort d'inventaire de 0,35 et 0,20 hommes-jours par placette respectivement dans les forêts denses et dans les forêts claires tropicales, étaient les plus efficaces pour la caractérisation phytosociologique de la végétation ligneuse.

\section{Introduction}

Forest inventories are carried out to provide necessary data on species to set standards for silviculture, to forecast the production and the evolution of the resources and to analyse the relationship between stations and their production (Fonweban \& Houillier, 1997).

During forest inventories, the unit of sampling often consists of plots whose shape and size vary according to the vegetation and the characteristics of the forest. 
Accurate characterization of the vegetation structure partially depends on inventory plot size; it is inversely proportional to the estimation bias of investigated parameters (Kenkel \& Podani, 1991; Shiver \& Borders, 1996). Nevertheless, the larger the plot, the longer the time and the higher the sampling effort and the cost of inventory (Kangas \& Maltamo, 2007). In practice, vegetation scientists have traditionally used the minimal area approach when characterizing the structure of plant communities (Kenkel \& Podani, 1991). Minimal area is generally defined as the plot size beyond which species richness fails to increase or increases only slightly. This minimal area is determined through an empirical pathway from the concept of species-area curve (Gounot, 1969). The use of the minimal area is straightforward. However, this approach has some problems (Barkman, 1989). In fact, it is based on presence-absence data rather than quantitative data (Roux \& Rieux, 1981; Dietvorst, Van der Maarel \& Van der Putten, 1982).

Apart from the plot size, another criterion to be taken into account in the reliability of forest inventories is the plot shape (Philip, 2002). Plot shapes can be circular, square or rectangular (Kenkel \& Podani, 1991; Rondeux, 1999; Kangas \& Maltamo, 2007). Circular plots represent the geometrical figure of lower perimeter for a given shape. Hence, they reduce the number of borderline trees, compared with to plot shapes in the same area (Kangas \& Maltamo, 2007). Rectangular plot shapes are reported to be more suitable for the inventory in planted forests (Van Laar \& Akça, 2007). Further, in tropical forests, it has been found to be more suitable to use square or rectangular plots (Van Laar \& Akça, 2007). Indeed, for a given surface, rectangular plots make it possible to count more species than other plot shapes (Jyrki, Vanha \& Tina, 1998).

Sampling of plant communities is a compromise between the precision of estimate of the species abundance in the vegetation and the inventory effort (Jyrki, Vanha \& Tina, 1998). Hence, plot patterns must be determined so as to reduce sampling effort and guarantee precision of estimates. Few studies have assessed and analysed the time necessary in forest inventories for data collection (Kenkel \& Podani, 1991); however, this parameter constitutes a major component of inventory efforts (Cheryl, Raphaël \& Claude, 2009). In a recent paper, Salako et al. (2013) reported that for the quantitative assessment of tropical woodland, an inventory effort of 0.51 man-day is adequate for a plot size of $1800 \mathrm{~m}^{2}$. According to some authors, inventory effort is often difficult to assess accurately because of the elasticity or nonlinearity of time to inventory trees (Norman, 1973).

In Africa and particularly in West Africa, size and shape of inventory plots are often chosen according to the experience of foresters. This leads to a high diversity of size and shape of plots in the same country. For example, square, rectangular or circular plots of various sizes, 314-1500 $\mathrm{m}^{2}$, are often used in phytosociological studies of stands in different vegetation types (Ganglo \& de Foucault, 2006; Sokpon et al., 2006; Bonou et al., 2009). This high heterogeneity does not allow for comparisons of inventory outputs and undermines the accuracy of investigations, which are important to monitor and manage forest dynamics. A first study has been carried out to assess inventory plot patterns for quantitative analysis of tropical vegetation and revealed that direction and shape of plots did not significantly influence the precision of the quantitative analysis of vegetation. However, square plots turned to be suitable in practice and plot sizes of $1800 \mathrm{~m}^{2}$ and $2000 \mathrm{~m}^{2}$ were found to be optimal for quantitative assessment of woodland and dense forest, respectively (Salako et al., 2013).

This study was set up to study the efficiency of shape and size of inventory plots in phytosociological characterization of vegetation types focusing on tropical woodlands and dense forests. Specifically (i) the relationship between plot size and the accuracy of phytosociological characterization of vegetation of tropical woodlands and dense forests was modelled and (ii) the inventory effort required for a given subplot was assessed.

\section{Study area}

This study was carried out in the Lama Forest Reserve (tropical dense forest) and in the Bellefoungou Forest Reserve (tropical woodland). The Lama Forest Reserve is located in Southern Benin in the Dahomey Gap between $6^{\circ} 55^{\prime}$ and $7^{\circ} 00^{\prime}$ latitude North and $2^{\circ} 04^{\prime}$ and $2^{\circ} 12^{\prime}$ longitude East (Fig. 1). The total area of the forest is estimated at 16,250 ha. Rainfall regime in the reserve is bimodal from April to June and from September to November, with a mean annual rainfall of $1200 \mathrm{~mm}$. Mean temperature varies between 25 and $29^{\circ} \mathrm{C}$ and relative humidity between 69 and 97\%. Four main vegetation groups were identified in the dense forest: the young preforest fallow, the old preforest fallow, the degraded dense forest and the typical nondegraded dense forest. This study was carried out in the typical nondegraded dense forest (Bonou et al., 2009). 


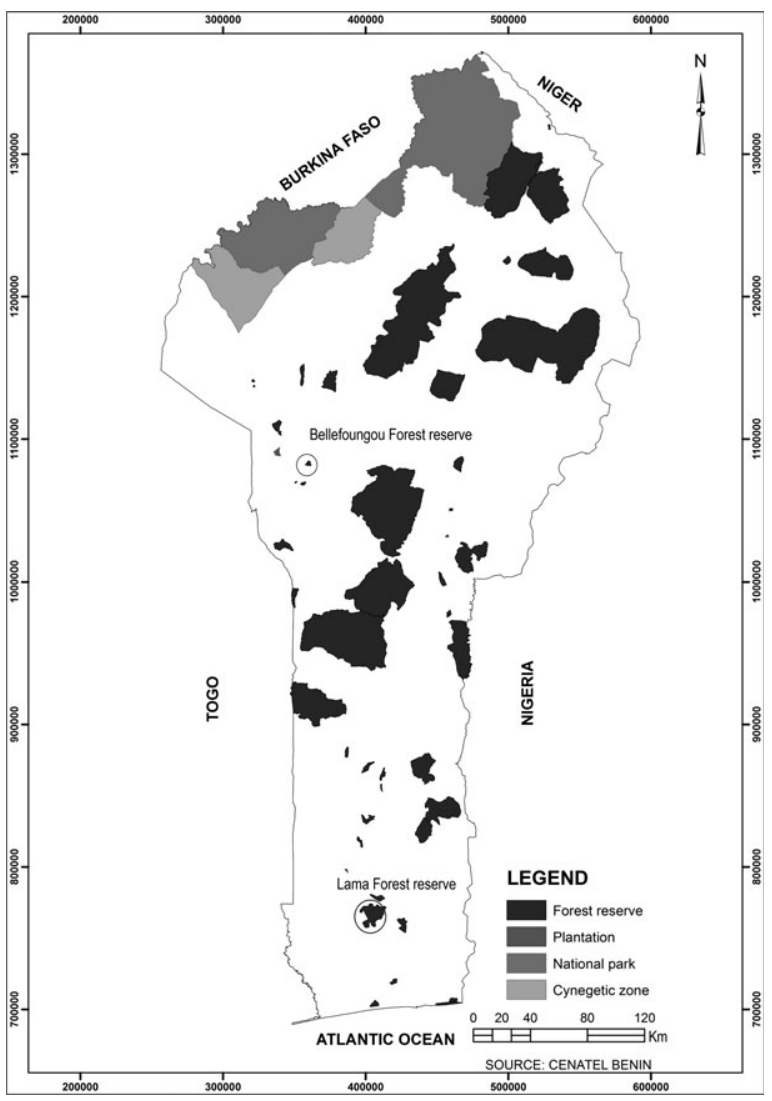

Fig 1 Location of Lama and Bellefoungou Forest reserve in Bénin

The Bellefoungou forest reserve is located in Northern Benin between $9^{\circ} 50^{\prime}$ and $10^{\circ} 00^{\prime}$ latitude North and $1^{\circ} 50^{\prime}$ and $2^{\circ} 50^{\prime}$ longitude East (Fig. 1). The total area of this forest is estimated at 709 ha. Rainfall regime in Bellefoungou is characterized by one rainy season from May to September and a dry season from October to April, with a mean annual rainfall of $1200 \mathrm{~mm}$. The annual mean temperature is about $28^{\circ} \mathrm{C}$. The vegetation is dominated by Isoberlinia spp. (Adomou, 2005; Houéto et al., 2013).

\section{Materials and methods}

\section{Forest inventory design and data collection}

Data were collected through forest inventory. Sampling units were laid out in the forest following a random sampling scheme. However, attention was paid to ensure the floristic homogeneity of the vegetation and the uniformity of ecological properties of stand as described by Braun-Blanquet (1932). Overall, 20 and 15 square

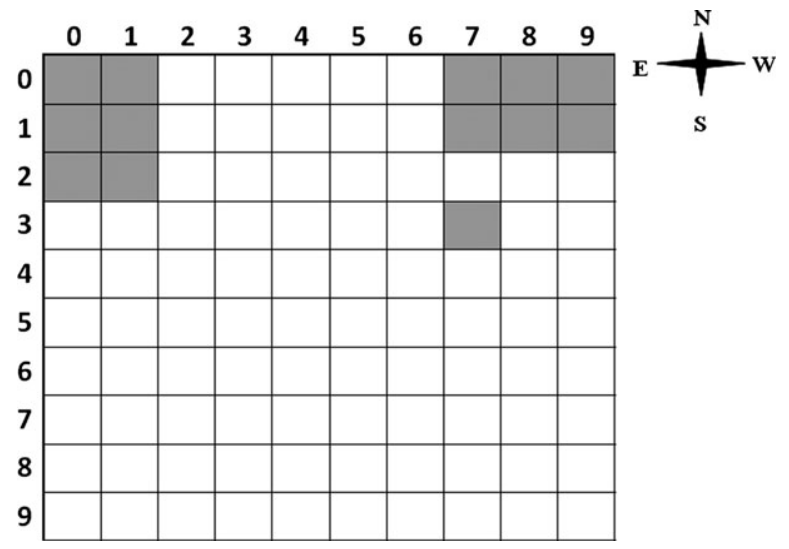

Fig 2 Sampling units of 1 ha with the 100 quadrats of $100 \mathrm{~m}^{2}$. Plot 37 is indicated in dark grey. Shaded regions in the top left are examples of the plot sizes and shapes considered in the analysis (see Table 1)

plots of 1 ha each were laid out, respectively, in dense forest and in woodland. Each 1 ha plot was divided into 100 quadrats of $100 \mathrm{~m}^{2}$ each (Fig. 2). The 1 ha plot served as reference in the assessment of the accuracy of the different sizes and shapes of plots considered in the study. Within each quadrat, a floristic record was made only on trees having a diameter at breast height (dbh) greater than $10 \mathrm{~cm}$. For each 1 ha plot, the time needed for an inventory team of three foresters to lay out the sampling units with the 100 quadrats and to record all observed tree species was noted. Also, the time spent in identifying tree species in five quadrats randomly chosen from each 1 ha plot was recorded.

Overall, the investigation covered 20 ha of dense forest representing $1.05 \%$ of the total surface covered by the typical dense forest of Lama and 15 ha representing $2.12 \%$ of the total surface covered by the Bellefoungou woodland.

Assessing the efficiency of inventory plots

Types of inventory subplots. Subplots were demarcated from the 100 quadrats in each 1 ha plot, by grouping together adjacent quadrats of $100 \mathrm{~m}^{2}$. Each type of inventory subplot was replicated a certain number of times in each 1 ha plot. In total, fourteen types of inventoried subplots were considered, and in each 1 ha plot, 284 subplots were defined (Table 1).

Figure 2 shows an illustration of a replicate of rectangular subplots of $600 \mathrm{~m}^{2}(20 \mathrm{~m} \times 30 \mathrm{~m})$ oriented North- 
South $(00,01,10,11,20,21)$ and a replicate of the same subplot oriented East-West (07, 08, 09, 17, 18, 19).

Computation of relative loss of accuracy (RLA) of the plot types. For each size and shape (square and rectangular) of plot, the coefficient of abundance $r$ i of each species was considered for the characterization of the vegetation types. The floristic description of a vegetation type was carried out by ordination of species abundance (multidimensional scaling and cluster analysis). Biased estimation of the abundance of the species can lead to an inaccurate description of the floristic structure of the vegetation. Accuracy is defined here in terms of reliable representation of the floristic structure of the community on the basis of abundance of each species estimated from plots of different sizes and shapes. The more accurate plot is the one that results in high compositional similarity among replicate plots; such a plot size minimizes the detection of community 'patchiness', which in turn implies an overall reduction in species variances and interspecific associations, that is, covariance structure (Dietvorst, Van der Maarel \& Van der Putten, 1982; Barkman, 1989). Covariance structure can be determined through an eigenanalysis of the species variance-covariance matrix (Orlóci, 1978). When covariance structure is high (species associations high, pairwise covariances large), the variance of eigenvalues will increase because the first few eigenvalues will be much larger than the others. Thus, a criterion that will help to measure the accuracy of phytosociological characterization of woody vegetation is the variance of the eigenvalues:

$C=\operatorname{variance}\left(\lambda_{i}\right)$

The algorithm used to compute the criterion of accuracy for each type of inventory subplots followed three steps:
Step 1. Considering a given subplot $k$, located in a 1 ha plot $t(k=1-284, t=1-20$ for dense forest and $t=1-15$ for woodland); the coefficient of abundance $r_{i t k}\left(i=1\right.$ to $p_{k}$ ) of a given species $i$ was computed as:

$r_{i t k}=q_{i t k} / \sum_{i=1}^{p k} q_{i t k}$

$q_{i t k}=$ absolute frequency of species $\mathrm{i}$ in subplot $\mathrm{k}$ of the 1 ha plot $\mathrm{t}$ and $p k=$ number of species observed in the plot $k$.

Step 2. For each subplot $k$, a matrix $M_{r}(20, p)$ or $M_{r}$ $(15, p)$ of coefficients of abundance of each species was constituted by grouping together the coefficients of abundance of the $p$ species over the 15 or 201 ha plots.

Step 3. The measure of accuracy (formula 1) was computed for each subplot $k: C_{k}$.

Illustration: let us consider the replication of the rectangular subplot $(\mathrm{L} / \ell=3 / 2)$ of size $600 \mathrm{~m}^{2}$ (Fig. 2, cells in grey). This subplot was replicated as the 1 ha plot replication, that is, twenty times in dense forest and fifteen times in woodland. But it was replicated 30 times in each 1 ha plot. Therefore, there were fifteen values of the criterion $\mathrm{cp}$ for this type of inventory subplot.

The relative loss of accuracy (RLA) of each type of inventory subplot was computed in comparison with a theoretical criterion of accuracy $\left(C_{\mathrm{T}}\right)$. This was determined with 1 ha plots following the first three steps of the previous algorithm. This empirical criterion $\left(C_{\mathrm{e}}\right)$ is biased. In fact, the theoretical criterion of accuracy $\left(C_{\mathrm{T}}\right)$ assumes the inventory of the whole stand, whereas only $2.12 \%$ and $1.05 \%$ of the forests were, respectively, inventoried in woodland and in dense forest in this study. So, the bootstrap technique (Efron \& Tibshirani, 1993) was used

Table 1 Types of subplots considered

\begin{tabular}{|c|c|c|c|c|}
\hline & \multicolumn{4}{|l|}{ Shape (m) } \\
\hline & Squared & Rectangular $(\mathrm{L} / \ell=3 / 2)$ & Rectangular $(\mathrm{L} / \ell=2)$ & Rectangular $(\mathrm{L} / \ell=3)$ \\
\hline \multirow[t]{4}{*}{ Size } & $20 \mathrm{~m} \times 20 \mathrm{~m}(25)$ & $30 \mathrm{~m} \times 20 \mathrm{~m}(30)$ & $20 \mathrm{~m} \times 10 \mathrm{~m}(100)$ & $30 \mathrm{~m} \times 10 \mathrm{~m}(60)$ \\
\hline & $30 \mathrm{~m} \times 30 \mathrm{~m}(9)$ & $60 \mathrm{~m} \times 40 \mathrm{~m}(4)$ & $40 \mathrm{~m} \times 20 \mathrm{~m}(20)$ & $60 \mathrm{~m} \times 20 \mathrm{~m}(10)$ \\
\hline & $40 \mathrm{~m} \times 40 \mathrm{~m}(4)$ & $90 \mathrm{~m} \times 60 \mathrm{~m}(2)$ & $60 \mathrm{~m} \times 30 \mathrm{~m}(6)$ & $90 \mathrm{~m} \times 30 \mathrm{~m}(6)$ \\
\hline & $50 \mathrm{~m} \times 50 \mathrm{~m}(4)$ & - & $80 \mathrm{~m} \times 40 \mathrm{~m}(4)$ & - \\
\hline
\end{tabular}

$\mathrm{L}=$ length of the subplots; $\ell=$ width of the subplots; values in brackets are the number of replications of each type of subplot in the two directions in a 1 ha plot. 
to correct the empirical criterion $\left(C_{\mathrm{e}}\right)$. The algorithm used to compute the bias of the empirical criterion of accuracy includes six steps:

Step 1. From the matrix $M(100, p)$ of the $p$ species absolute frequencies in each of the 100 quadrats of a given 1 ha plot, a bootstrapped matrix $M^{*}$ $(100, p)$ was generated by randomly selecting 100 rows of $M$.

Step 2. From the previous matrix $M^{*}(100, p)$, the $p$ species coefficient of abundance $\left(r_{i}^{*}\right)$ were computed.

$r_{i}^{*}=\sum_{l=1}^{100} q_{i l} / \sum_{i=1}^{p} \sum_{l=1}^{100} q_{i l}$

$q_{i l}=$ absolute frequency of species $i(i=1, \ldots, p)$ in the quadrat $L(L=1, \ldots, 100)$ of a given 1 ha plot; note that the denominator is the total number of tree in the bootstrapped matrix.

Step 3. Steps 1 and 2 were applied to each of the twenty matrices (corresponding to the 21 ha plots in dense forest) and the fifteen matrices (corresponding to the 51 ha plots in woodland).

Step 4. A matrix $M_{r}^{*}(20, p)$ in dense forest or $M_{r}^{*}(15, p)$ in woodland was constituted, and the criterion of accuracy $C^{*}$ (Eq. 1) was then computed.

Step 5. Steps 1-4 were repeated 1000 times so as to obtain 1000 values of the criterion $C^{*}$. The criterion arithmetic mean, $\bar{C}$ and the plugging estimator, $C_{\mathrm{pg}}$ (Palm, 2002) were calculated.

Step 6. The bias closed to the estimation of the theoretical criterion of accuracy $\left(C_{\mathrm{T}}\right)$ using the bootstrap (Efron, 1982) is:

bias $=\bar{C}-C_{\mathrm{pg}}$

The unbiased value of the theoretical criterion of accuracy $\left(C_{\mathrm{T}}\right)$ is therefore:

$C_{T}=C_{e}-$ bias

The relative loss of accuracy (RLA) of a subplot $k$ in a 1 ha plot was then computed as follows:

$\operatorname{RLA}(\%)=100\left(C_{p k}-C_{T}\right) / C_{T}$

Hence, the smaller the RLA, the more accurate the subplot will be in the phytosociological characterization of the woody vegetation.
Computation of the mean sampling effort, $W_{\left(n^{*} 100 m^{2}\right)}$. The mean sampling effort is the second parameter (after RLA), which allows for the study of efficiency in a given subplot compared with others. Efficiency here refers to obtaining an accurate result at the lowest possible time and cost. For a given subplot of size $\mathrm{n}^{*} 100 \mathrm{~m}^{2}$, the mean sampling effort $\left(W^{*}\left(\mathrm{n}^{*} 100 \mathrm{~m}^{2}\right)\right.$ ) for a team of three foresters was computed as:

$W_{\left(\mathrm{n} * 100 \mathrm{~m}^{2}\right)}^{*}=\mathrm{nW}_{(1 \mathrm{ha})} / 100 \tau$

In Eq. $7, W_{(1 \text { ha) }}$ is the mean sampling effort (in mandays) of the 1 ha plot. The time needed to lay out the inventory scheme (Fig. 2) and to identify species was summed, and the conversion table of Norman (1973) was used to convert data expressed as minutes in data expressed as man-days; where $\tau$ is a coefficient of lengthening of time ( $\tau=\bar{t}_{r c} / \alpha$ ). It was considered necessary to take into account the lengthening of the human sampling effort during a day. $\bar{t}_{r c}$ means sampling time per quadrat, obtained with the five random quadrats and $\alpha$ also the mean sampling time per quadrat, but obtained when assuming a proportional rule between quadrats and the 1 ha plots.

Comparison of types of subplots. A covariance analysis (size as covariable) was performed to compare the subplots shape according to their RLA. Moreover, two curves were established in a 3-axes graph. The first described the evolution trend of the RLA (axis 1) versus shape and size of subplots and the second described the variation of the sampling effort for the phytosociological characterization of the vegetation (axis 2).

\section{Results}

Efficiency of shape and size of subplots in the phytosociological characterization

Effect of subplot shape. The phytosociological characterization of the woody vegetation was not influenced by subplot shape (Table 2). Overall either square or rectangular subplots resulted in similar accuracy of the vegetation description. In contrast, results indicated that plot size highly influenced the accuracy of phytosociological characterization $(P<0.01)$.

Effect of subplot size. The modelling of the relationship between RLA, sampling effort and plot size (Fig. 3) showed 
Table 2 Effect of subplot shape on the RLA: results of covariance analysis $($ covariable $=$ size $)$

\begin{tabular}{llrllllll}
\hline & \multicolumn{3}{l}{ Dense forest } & & \multicolumn{3}{l}{ Woodland } \\
\cline { 2 - 3 } \cline { 7 - 8 } Source of variation & df & $F$-value & $P$ & & df & $F$-value & $P$ \\
\hline Size & 1 & 21.05 & 0.001 & & 1 & 38.92 & 0.000 \\
Shape & 3 & 0.26 & 0.851 & & 3 & 0.26 & 0.855 \\
\hline
\end{tabular}

that RLA decreases while plot size increases. Decreases were most pronounced at the smaller plot size for both dense forest and woodland. The accuracy of phytosociological characterization can be improved by increasing plot size. However, this includes increase in the sampling effort. The analysis of Fig. 3 showed that the increase in RLA is not very perceptible around $1500 \mathrm{~m}^{2}$ (in dense forest) and $1000 \mathrm{~m}^{2}$ (in woodland) suggesting that subplots of $1500 \mathrm{~m}^{2}$ and $1000 \mathrm{~m}^{2}$ could provide a good accuracy of the phytosociological characterization of the vegetation with a minimum sampling effort of 0.35 man-days/subplot and 0.2 man-days/subplot, respectively, in dense forest and in woodland.

\section{Discussion}

This study documents the efficiency of plot shape and size in phytosociological characterization of dense forest and woodland in tropical Africa. The design used (Fig. 2) focused on right angle plots (i.e. square and rectangular) with various sizes. The inventory design is of great importance in the reliability of data collected (Økland, 1990). However, the design used did not consider circular plots, which are also used in the vegetation studies (Kangas \& Maltamo, 2007; Van Laar \& Akça, 2007). They are often considered for (i) their ease of establishment with aid of optical devices (Husch, Beers \& Kershaw, 2003) and (ii) the reduction in borderline trees (Philip, 2002). They are also convenient when the studies are related to the planted forests (Van Laar \& Akça, 2007). However, in developing countries, the lack of suitable facilities (e.g. optical devices) limits the use of circular plots in natural forests. To avoid the difficulty of circular plots establishment and to improve on efficiency, designs combining right angle and circular plots are used (Glèlè Kakaï, Sinsin \& Palm, 2008), although often for multistage sampling purposes.

In forest inventories, the sampling design is also of great importance. It depends on the environmental properties, for example structural complexity of the vegetation and
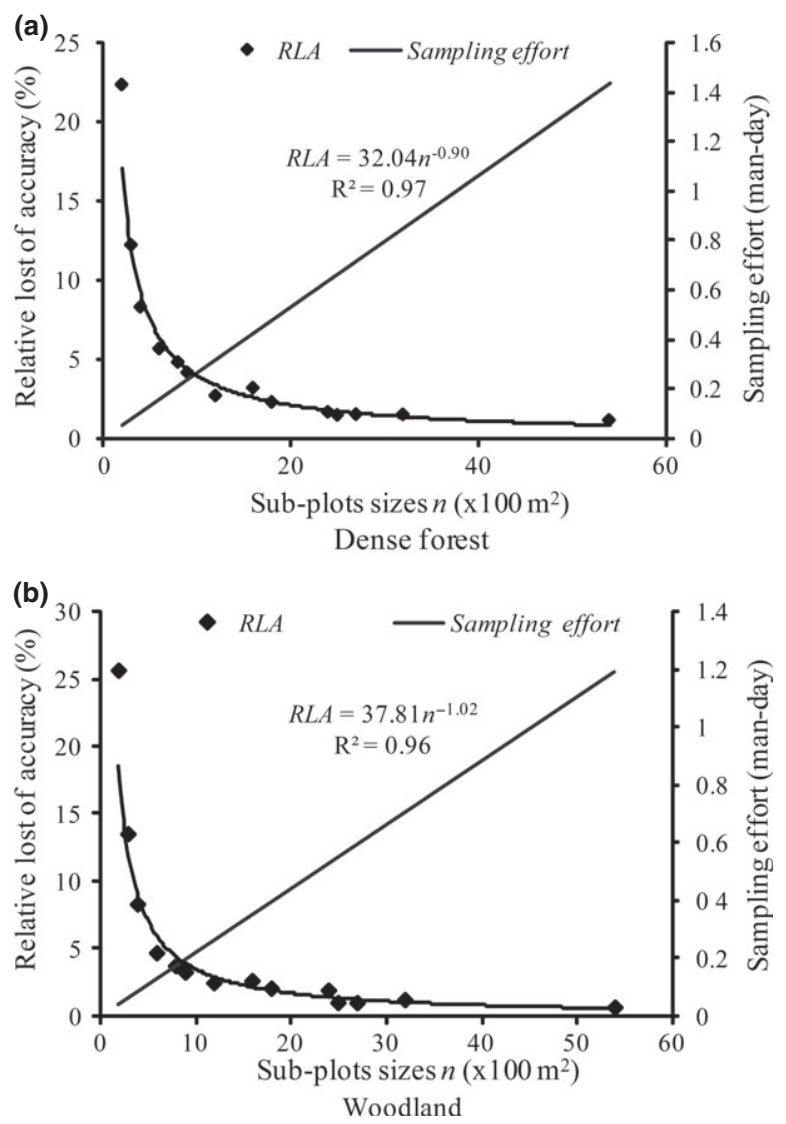

Fig 3 Relationship between the relative loss in accuracy (RLA) of phytosociological characterization of the vegetation, subplot sizes and sampling effort for the two vegetation types

ecology (Husch, Beers \& Kershaw, 2003). The random scheme used in this study is well adapted to homogeneous vegetation types such as the typical dense forest of Lama (Bonou et al., 2009) and Bellefoungou.

The efficiency of inventory designs also includes the time spent to move from one plot to the next one (Zeide, 1980; Van Laar \& Akça, 2007). The methodology to compute the mean sampling effort, designed in the current research, assumes a linear relationship of the time of inventory of the 1 ha plot between the 100 quadrats. The intensity of labour that determines the inventory time is a nonlinear factor (Norman, 1973). Even if a better way should have been to record the inventory time for each of the 100 quadrats in each of the 1 ha plots, the implementation would have been difficult or even impossible. However, the coefficient of extension of time has been included to correct for this. 
Plot shape is of importance in the reliability of forest inventory (Økland, 1990; Rondeux, 1999; Kangas \& Maltamo, 2007). The findings from this study indicate that plot shape did not impact on accuracy of phytosociological characterization of the woody vegetation. Kulow (1966), Grayet (1977), Picard (2006) have previously shown that plot shape only slightly influences estimation accuracy. However, Rondeux (1999), Kangas \& Maltamo (2007) preferred square plots to rectangular ones. In fact, rectangular plots have been found to be most suitable for communities with a strongly clustered spatial pattern of species (Jyrki, Vanha \& Tina, 1998). More species are encountered using rectangular plots than circular or square ones on the same area in such communities (Podani, 1984; Condit et al., 1996).

As for the plot shape, plot size is also crucial in estimation accuracy (Kenkel \& Podani, 1991). Fourteen plot shapes were considered to test the effect of plot size in this study. From the results, it was noticed that the estimation accuracy can be improved by increasing plot size (Kenkel \& Podani, 1991; Jyrki, Vanha \& Tina, 1998; Cheryl, Raphaël \& Claude, 2009). In fact, it is obvious that the larger the plot size, the more precise the mapping of species association. However, this work was not about identifying the most accurate type of plot but in the type of plot that results in the highest precision with the lowest inventory effort. Square plots of $1000 \mathrm{~m}^{2}$ appeared to be the most efficient type of plot. It is less time consuming, and up to this area the accuracy increases only slightly. The most efficient type of plot is more effort consuming in dense forest (0.26 man-day/subplot) than in woodland (0.22 man-day/subplot), which can be explained by the structural features like tree-density and heavy undergrowth in the forest.

Findings from this study should only be valid in the case of vegetation types considered: woodlands and dense forests. Further studies should target other vegetation types.

\section{Acknowledgements}

This work has been financially supported by the Economic Community of West African States (ECOWAS) and the Academy of Sciences for the developing world.

\section{References}

ADomou, C.A. (2005) Vegetation Patterns and Environmental gradients in Benin. Implications for biogeography and conservation $\mathrm{PhD}$ thesis, Wageningen University, The Netherlands.

BARKMAN, J.J. (1989) A critical evaluation of minimum area concepts. Vegetatio 85, 89-104.

Bonou, W., Glèlè Kakaï, R., Assogbadjo, A.E., Fonton, H.N. \& Sinsin, B. (2009) Characterisation of Afzelia africana Sm. habitat in the Lama forest reserve of Benin. For. Ecol. Manage. 258, 1084-1092.

Braun-Blanquet, J. (1932) Plant Ecology: The Study of Plant Communities (English Translation). McGraw-Hill, New York, USA.

Cher yl, D.N., Raphä̈L, P. \& Claude, G. (2009) Comparative efficiency and accuracy of variable area transects versus square plots for sampling tree diversity and density. Agrofor. Syst. 79, 223-236.

Condit, R., Hubbell, S.P., Lafrankie, J.V., Sukumar, R., Manokaran, R., Foster, R.B. \& Ashton, P.S. (1996) Species-area and speciesindividual relationships for tropical trees: a comparison of three 50-ha plots. J. Ecol. 84, 549-562.

Dietvorst, P., Van der Maarel, E. \& VAn der Putten, H. (1982) A new approach to the minimal area of a plant community. Vegetatio 50, 77-91.

EFron, B. (1982) The Jackknife, The Bootstrap and Other Resampling Plans. SIAM, Philadelphia, USA.

Efron, B. \& Tibshirani, R.J. (1993) An Introduction to the Bootstrap. Chapman and Hall, New York, USA.

FonwebAn, J.K. \& HoullLIER, F. (1997) Eucalyptus sativa: Tarifs de peuplement et modèles de production. Bois et forêt des tropiques 253, 21-36.

Ganglo, J.C. \& De Foucault, B. (2006) Plant communities, forest site identification and classification in Toffo reserve, SouthBenin. Bois et forêt des tropiques 288, 25-38.

GlèLè KaKaï, R., Sinsin, B. \& PALM, R. (2008) Etude dendrométrique de Pterocarpus erinaceus Poir. des formations naturelles de la zone soudanienne au Bénin. Agronomie Africaine 20, 233255.

Gounot, M. (1969) Méthodes d'études quantitatives de la végétation. Masson et Cie, Paris, France.

GRAYET, J.P. (1977) Contribution à l'étude de l'échantillonnage en futaie feuillue. Annales des sciences forestières 34, 59-75.

HouÉto, G., Fandohan, B., OuÉdraogo, A., Ago, E., Salako, V.K., Assogbadjo, A.E., Glele KaKaï, R. \& Sinsin, B. (2013) Floristic and dendrometric analysis of woodlands in the Sudano-Guinean zone: a case study of Belléfoungou forest reserve in Benin. Acta Bot. Gall. 159, 387-394.

Husch, B., BeErs, T. \& Kershaw, J.J.R. (2003) Forest Mensuration, 4th edn. John Wiley \& Sons, New Jersey, USA.

Jyrki, J., VANHA, I. \& TinA, T. (1998) Optimal sample and plot size for inventory of field and ground layer vegetation in a mature Myrtillus-type boreal spruce forest. Ann. Bot. Fennici 35 , 191-196.

Kangas, A. \& Maltamo, M. (2007) Forest Inventory: Methodology and Applications. Springer, Dordrecht, England.

KenKEL, N.C. \& PoDAnI, J. (1991) Plot size and estimation efficiency in plant community studies. J. Veg. Sci. 2, 539-544. 
Kulow, D.L. (1966) Comparison of forest sampling designs. J. Forest. 64, 469-474.

Norman, D.W. (1973) Methodology and problems of farm management investigations. Experience from northern in Nigéria. Africa Rural Employment. Research paper $\mathrm{N}^{\circ} 8$ Ahmadou Bello University Zaria, Nigéria.

ØKLAND, R.H. (1990) Vegetation Ecology: Theory, Methods and Applications With Reference to Fennoscandia. Sommerfeltia Supplement pp 1-123.

ORLócI, L. (1978) Multivariate Analysis in Vegetation Research, 2nd edn. Junk, The Hague, Holland.

PALM, R. (2002) Utilisation du bootstrap pour les problèmes statistiques liés à l'estimation des paramètres. Biotechnology, Agronomie, Société, Environnement 6, 143-153.

PHILIP, M.S. (2002) Measuring Trees and Forests, 2nd edn. CABI, London, England.

Picard, N. (2006) Méthode d'inventaire forestier. Projet de développement rural participatif dans le moyen Atlas central (projet Khénifra). Report, Cirad 00147247; 42p.

PoDANI, J. (1984) Spatial processes in the study of vegetation: theory and review. Acta Bot. Hung. 30, 75-118.

RonDeux, J. (1999) La mesure des peuplements forestiers, 2ème éd. Presses agronomiques de Gembloux, Gembloux, Belgique.
Roux, C. \& Rieux, R. (1981) L'aire minimale des peuplements lichéniques saxicoles-calcicoles. Vegetatio 44, 65-76.

Salako, V.K., Glele Kakaï, R.L., Fandohan, B., Assogbadjo, A.E., Houinato, M. \& PaLM, R. (2013) Efficiency of inventory plot patterns in quantitative analysis of vegetation: a case study of tropical woodland and dense forest in Benin. Southern Forests: a Journal of Forest Science doi:10.2989/20702620.2013. 816232.

SHIVER, B.D. \& Borders, B.E. (1996) Sampling Techniques for Forest Resource Inventory. Wiley \& Sons, New York, USA.

Sokpon, N., Biaou, S.H., Ouinsavi, C. \& Hunhyet, O. (2006) Bases techniques pour une gestion durable des forêts claires du NordBénin: rotation, diamètre minimal d'exploitabilité et régénération. Bois et forêts des tropiques. 287, 45-57.

VAn LaAr, A. \& АкÇA, A. (2007) Forest Mensuration. Springer, Dordrecht, England.

ZEIDE, B. (1980) Plot size optimization. Forest Sci. 26, 251-257.

(Manuscript accepted 28 July 2013)

doi: 10.1111/aje.12112 